\title{
Moving Toward Decent Work: Application of the Psychology of Working Theory to the School-to-Work Transition
}

Journal of Career Development

(C) Curators of the University of Missouri 2021 Article reuse guidelines: sagepub.com/journals-permissions DOI: $10.1177 / 0894845321991681$ journals.sagepub.com/home/jcd

(SAGE

\author{
Jonas Masdonati ${ }^{1,2} \oplus$, Koorosh Massoudi ${ }^{1,2}$, David L. Blustein ${ }^{3}$, \\ and Ryan D. Duffy ${ }^{4}$
}

\begin{abstract}
This conceptual contribution aims to adapt and apply Psychology of Working Theory to the specificities of the school-to-work transition (STWT) process. The STWT is thus conceptualized as a first attempt to access decent work under the influence of specific predictors, mediators, and moderators and leading to particular outcomes. Based on recent literature, we consider that (I) socioeconomic constraints and belonging to marginalized groups are contextual predictors of a successful transition; (2) psychosocial resources, including self-efficacy and adaptability, and vocational and work role identity, are mediators of the relation between contextual factors and a successful transition; (3) moderator factors include the education system, labor market conditions, social support, and critical consciousness; and (4) decent and meaningful work are the optimal outcomes of the STWT process.
\end{abstract}

\section{Keywords}

school-to-work transition, Psychology of Working Theory, decent work, meaningful work

Since the late 1990s, the topic of work-based transitions, particularly the transition from school to work, has received increasing attention in the field of career development and vocational psychology (e.g., Lent \& Worthington, 1999). Scholars reported that moving from education toward the labor market, far from being a trivial and automatic transition, had become a particularly challenging developmental task, exposing many young adults to insecure integration into the world of work (Blustein et al., 2002; Krahn et al., 2015). Some 20 years after initial exploration, the topic is still significant, with studies focusing on the challenges encountered by marginalized young adults (not in education, employment, or training [NEET], e.g., International Labor Organization [ILO], 2019; Organization for

\footnotetext{
' Swiss National Centre of Competence in Research LIVES, University of Lausanne, Switzerland

${ }^{2}$ Institute of Psychology, University of Lausanne, Switzerland

${ }^{3}$ Department of Counseling, Developmental, and Educational Psychology, Boston College, Chestnut Hill, MA, USA

${ }^{4}$ Department of Psychology, University of Florida, Gainesville, FL, USA
}

\section{Corresponding Author:}

Jonas Masdonati, Institute of Psychology, University of Lausanne, Géopolis 4239, CH-10I5 Lausanne, Switzerland. Email: jonas.masdonati@unil.ch 
Economic Co-operation and Development [OECD], 2017), on the new competences that adolescents and emerging adults need to master to cope with unpredictable trajectories (Akkermans et al., 2015), and on the effects of globalization on the school-to-work transition (STWT; Schoon \& Silbereisen, 2009).

Subsequently, theoretical conceptualizations of careers have evolved, going beyond a focus on individual factors to also take into account contextual determinants of professional paths. Among such contemporary approaches, Psychology of Working Theory (PWT; Blustein, 2006, 2013; Duffy et al., 2016) stresses the need for a multidisciplinary approach to career development, drawing from different fields such as organizational psychology, sociology, and economics to better understand the needs of marginalized people and the obstacles they face when trying to access decent work. The aim of this article is to adapt PWT to the STWT in order to deepen our understanding of the contextual and psychosocial factors that influence and shape this challenging transition.

\section{Approaches of STWTs}

Scholars from a diverse array of disciplines have examined STWT. For example, vocational psychologists have mainly studied STWT challenges in terms of decision-making processes and adaptation skills (e.g., Masdonati \& Fournier, 2015; Murphy et al., 2010), whereas scholars in management and work and organizational psychology have focused on socialization processes when studying newcomers' efforts to integrate into the labor market (e.g., Ng \& Feldman, 2007; Saks et al., 2007). Developmental psychologists, for their part, consider the STWT as a key developmental task that emerging adults have to undertake concurrently with other life transitions that characterize the passage toward adulthood (e.g., Dietrich et al., 2012; Pinquart et al., 2003). Furthermore, research in the field of education focuses on the ways school systems facilitate or impede the entry into the labor market (e.g., Nägele \& Neuenschwander, 2014; Schoon \& Heckhausen, 2019), whereas sociology highlights inequalities and exclusion processes that some young adults experience during the transition, and how social changes can impact their careers (e.g., Krahn et al., 2015; Vuolo et al., 2014). Following the recommendation of scholars within the fields of vocational psychology and career development, we seek to build on this multidisciplinary interest to better understand the complexity of STWT processes.

\section{PWT and the STWT}

The Psychology of Working Framework (PWF; Blustein, 2006, 2013) represents an attempt to draw on inputs from various disciplines to understand the challenges faced by adults as they negotiate workrelated tasks across the life span. PWF advocates for an inclusive approach to working, recognizing the difficulty in accessing decent jobs for workers as well as the challenges faced by people who aspire to work but are excluded from the labor market. Based on this framework, PWT (Duffy et al., 2016) consists of a theoretical and empirical model of decent work. PWT identifies predictors, mediators, moderators, and outcomes of decent work in terms of (1) contextual factors, such as economic constraints and marginalization processes, which determine the chances to access decent work; (2) psychosocial factors like work volition and career adaptability, which mediate the relations between predictors and decent work; (3) proactive personality, critical consciousness, social support, and economic conditions as moderators of these relations; and (4) decent work leading to the opportunity of satisfying survival, social connection, and self-determination needs, which in turn positively affects work fulfillment and general well-being.

By addressing issues of work for adults engaged in and those struggling to access the labor market, PWT informs the conceptualization of career transitions of people struggling for decent work conditions. However, the theory is not directly applicable to the situation of young adults at the 
interface between school and work, and this is mainly due to two characteristics of this transition. First, the STWT generally concerns emerging adults who are dealing with age-related challenges in terms of developmental tasks and identity formation and thus form a population with specific characteristics and needs (Grosemans et al., 2018; Murphy et al., 2010). Second, its particular status as the first major transition of a future career ( $\mathrm{Ng} \&$ Feldman, 2007; Saks, 2018) confers the STWT with features that differentiate it from other work transitions such as mobility or career changes (Medvide et al., 2019).

The STWT has unique and somewhat critical characteristics that have an impact on people's entire career path (ILO, 2019; Ng \& Feldman, 2007; Pinquart et al., 2003; Vuolo et al., 2014). Given the importance of this process, it is crucial to propose an up-to-date perspective about the features and forms of a successful transition within the current socioeconomic context and to depict its main contextual and psychosocial determinants (Schoon \& Silbereisen, 2009). Doing so should propel future research on the STWT and elaborate interventions to facilitate smooth access to decent and meaningful work and promote sustainable career development (De Vos et al., 2018; Medvide et al., 2019). In the following sections, we will attempt such a reflection by applying and adapting PWT to the specific challenges of the STWT as identified based on psychological, educational, and sociological literature on the subject. Unlike the original PWT paper (Duffy et al., 2016), our goal is not to provide detailed theoretical or empirical support for each relation in the model. We aim rather to identify how the key factors within PWT (i.e., contextual predictors, psychosocial mediators, individual and contextual moderators, and outcomes in terms of decent and meaningful work) manifest themselves in the STWT and how they may influence the specific challenges of this transition.

Figure 1 shows how the proposed STWT model is grounded in the PWT. Both models share their focus on socioeconomic constraints and marginalization as key determinants of outcomes in terms of access to decent work or success of the transition. Both PWT and the STWT model also highlight the mediating role of career adaptability and the moderating role of labor market conditions, critical consciousness, and social support on the link between predictors and outcomes. However, the STWT model presents five specific attributes. First, successful STWT is our model's core element, whereas decent work - together with meaningful work-represents ideal yet distal outcomes of the transition. Second, the education system is added as a moderator factor in the process of moving from school toward the labor market. Third, we added identity issues as a mediator since identity formation represents a critical developmental task of emerging adults in transition (Grosemans et al., 2018). Fourth, work volition is replaced by self-efficacy, as several studies have documented the impact of self-efficacy on the ability to cope with adversity during the STWT process (e.g., Ng \& Feldman, 2007). Finally, we removed proactive personality as a moderator factor since the literature is somewhat equivocal regarding the influence of personality on the STWT and that personality is shown to be less stable in young populations still dealing with essential developmental tasks (e.g., Hopwood et al., 2011).

\section{Successful STWTs}

The STWT is traditionally defined as the movement from school toward full-time employment and the role transition from student to worker (Saks, 2018; Schoon \& Heckhausen, 2019; Vuolo et al., 2014). Consequently, a successful STWT involves finding a job, performing well at the workplace, and developing positive work attitudes ( $\mathrm{Ng} \&$ Feldman, 2007). However, such a definition reveals insufficient to grasp the increasing complexity and diversity of paths and processes, which lead to integration in the contemporary labor markets (Akkermans et al., 2015; Krahn et al., 2015; Ling \& O'Brien, 2013). Therefore, in order to adopt a contemporary understanding of STWT, we postulate that a successful transition should be defined not only through objective indicators (finding a job and being in 


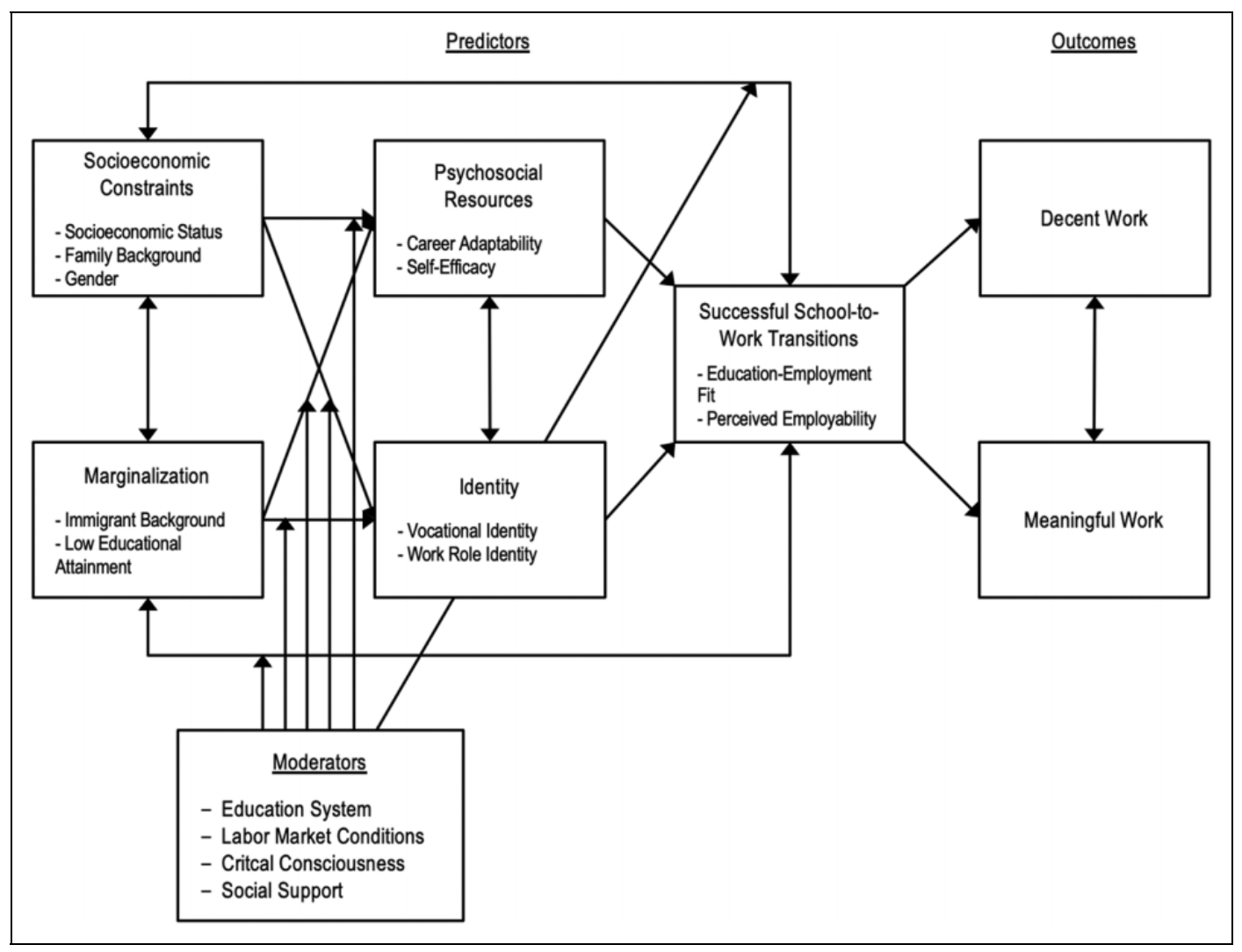

Figure I. Theoretical model of the school-to-work transition predictors and outcomes from a Psychology of Working Theory perspective.

employment) but also based on subjective indicators, namely the education-employment fit (Ling \& O’Brien, 2013) and perceived employability (Peeters et al., 2019).

Education-employment fit. Research on underemployment stresses that being unable to find a "quality" job can have negative effects on individuals and their relation to work (Kim \& Allan, 2019; Koen et al., 2014). A crucial form of underemployment that might affect the STWT stems from a misfit between the current job and the education or training achieved (Medvide et al., 2019) and can take two forms (Danziger \& Ratner, 2010). First, a gap can exist between the type of education and the type of job: When forced to accept a job outside their field of education or training, young adults are unable to utilize their competences and need to learn new ones from scratch. Second, this misfit can also refer to a gap between the level of education and the occupational status, resulting in overqualified workers experiencing a lack of recognition and some disappointment about their options. We thus posit that a successful transition is one that brings young adults to find a job in line with their education and protects them from underemployment.

Perceived employability. When entering the labor market, young adults are often likely to experience a period of employment fluctuations (Krahn et al., 2015; Ling \& O’Brien, 2013; OECD, 2010). Their judgment about their ability to remain employable throughout these fluctuations is therefore fundamental to their work integration. Defined as the perception of one's ability to access and maintain 
employment within or across organizations, perceived employability was indeed shown to reduce the risk of unemployment and job insecurity (Peeters et al., 2019). Perceived employability is therefore considered as a second central indicator of a "sustainable start" for young adults in the labor market (Blokker et al., 2019). Even though we acknowledge the importance of employability to cope with the challenges of STWT, we also recognize the limits of overemphasizing individual resources to compensate the excessive uncertainty and insecurity induced by unregulated labor markets. Rather than a mere individual characteristic, employability should thus be conceived as a contextual and relational phenomenon (Forrier et al., 2018).

\section{Predictors}

Contextual predictors influence, either directly or indirectly, the likelihood to experience a successful STWT. The relevant educational and sociological literature reveals that experiencing socioeconomic constraints and belonging to marginalized groups expose young adults to adverse transitional outcomes (Holtmann et al., 2017; OECD, 2010; Schoon \& Silbereisen, 2009).

\section{Socioeconomic Constraints}

The first contextual group of predictors includes socioeconomic constraints affecting young adults in transition. Specifically, sociological approaches highlight the impact of socioeconomic status, family context, and gender on the STWT.

Socioeconomic status. According to Schoon and Heckhausen (2019), young adults' social status has an influence "on material, cultural and social resources, and the 'horizon of perceived possibilities' (i.e. the perception about what career options are available and appropriate to strive for)" (p. 140). In a similar way, Blustein et al. (2002) stressed that when facing the STWT and compared with peers of higher socioeconomic status, disadvantaged young adults are impeded in their access to external resources, show lower levels of adaptability, and a less crystallized self-concept. More specifically, social status influences several factors that affect the ease and speed of the STWT (Rojewski \& Kim, 2003). For instance, youth of low socioeconomic status present lower aspirations (Schoon \& Polek, 2011), higher probability of experiencing tumultuous transitions (Vuolo et al., 2014), and decreased chances of accessing employment or training when leaving school (Ng-Knight \& Schoon, 2017).

Family background. Family background plays a crucial role in the transition process (Ling \& O'Brien, 2013). The family influence on adolescents' academic achievement and career development is conveyed through different mechanisms such as parents' attachment styles, their attitudes toward their children's career choices, or their involvement in school activities (Kenny \& Medvide, 2013). Specifically for the STWT, family members convey representations of work that are more or less realistic and can provide young adults with different degrees of aspirations and self-confidence in face of the transition challenges (Masdonati \& Fournier, 2015). For example, Bynner and Parsons (2002) showed that, in the UK, the probability of being a NEET is higher when parents do not show interest in their children's education. Moreover, family background determines the quality of the network young adults can rely on when searching a job (Schoon \& Heckhausen, 2019).

Gender. Even though women tend to have higher aspirations and similar academic and occupational attainments when compared to men, they generally earn lower salaries (OECD, 2016; Schoon \& Polek, 2011) and are overrepresented among NEETs (ILO, 2019). Although gender inequalities mainly touch working adults, young people who are transitioning to the labor market face gender discrimination, which in turn leads to unequal access to different occupational sectors (Imdorf et al., 2015; Schoon \& Polek, 2011). As an example, women students are overrepresented in the field of education studies 
while underrepresented in engineering in OECD countries (OECD, 2016). Considering that these "gender imbalances in fields of study are mirrored in the labor market - and ultimately in earnings" (p. 29), it appears that women's career choices may be limited to a smaller range of lower paying occupations.

These three forms of socioeconomic constraints are interconnected. Indeed, young adults' family background largely determines their socioeconomic status (Blustein et al., 2002; Ling \& O'Brien, 2013). As for gender, international comparative research shows that the link between parents' lack of implication and the risk of precarious transition or exclusion is stronger for girls than for boys (Imdorf et al., 2015).

\section{Marginalization}

Belonging to marginalized social groups is the second contextual factor that threatens the STWT process. Among these groups, young adults with immigrant background and those with low educational attainments are particularly at risk of adverse outcomes.

Immigrant background. Young adults' background in terms of immigration and ethnic origin affects their STWT process and undermines their efforts to participate in the labor force through two types of obstacles. First, ethnic minorities might experience social barriers and discrimination, which threaten their school performance and hinder their equitable access to work opportunities (Ali \& Menke, 2014; Marshall et al., 2011). Second, young immigrants or refugees are exposed to difficulties when coping with STWT since they concurrently have to deal with the challenges of relocation. Evidence highlights indeed that, compared to their native-born peers, youth with an immigrant background show higher levels of school dropout (Ali \& Menke, 2014), lower levels of educational attainment (OECD, 2016) and have access to fewer opportunities for decent employment and positive career development (Yakushko et al., 2008).

Low educational attainment. In knowledge-based societies, qualifications have a central and increasing importance as determinants of integration in the labor market (Medvide et al., 2019; OECD, 2010, 2016). Indeed, educational attainment is shown to predict the quality of career paths, leading college and university students to experience smoother STWTs than noncollege and work-bound youth (Blustein et al., 2002; Ling \& O’Brien, 2013; OECD, 2017; Rojewski \& Kim, 2003; Saks, 2018; Vuolo et al., 2014). Given the centrality of school performance as a selection criterion for employers (Akkermans et al., 2015), underperforming pupils and school leavers are impeded in their efforts to find a job (Holtmann et al., 2017). Furthermore, noncompletion of an upper secondary qualification is recognized as a central threat to young adults' employability (OECD, 2017).

Even though young people with low educational attainment and immigrant background constitute two main at-risk groups during the STWT, other marginalized groups are also exposed to difficult transitions. For example, sexual minorities (e.g., Chen \& Keats, 2016) or young adults with disabilities (Feldman, 2004) need to cope with specific constraints or barriers through their transitions. Finally, it appears that the different predictors of the STWT are interconnected. For instance, immigrants are generally overrepresented among low qualified youths (OECD, 2016), which seems to remind the sociological principle of cumulative risk (Ng-Knight \& Schoon, 2017).

\section{Mediators}

In line with the principles of PWT, our model posits that the relation between contextual predictors and the outcomes of the STWT is mediated by psychosocial factors. These factors can be divided into psychosocial resources and identity processes. 


\section{Psychosocial Resources}

PWT identifies career adaptability and work volition as mediator factors between contextual predictors and decent work. In our model, we replaced work volition with self-efficacy beliefs because, while both concepts are akin, the literature strongly supports the critical role of self-efficacy on STWT processes and outcomes (Duffy et al., 2015). We then propose career adaptability and self-efficacy as two key psychosocial resources during the STWT process.

Career adaptability. Career adaptability "denotes an individual's resources for coping with current and anticipated tasks" within the career domain (Savickas \& Porfeli, 2012, p. 662), and the STWT is considered as one of these tasks (Medvide et al., 2019). The construct is divided into four dimensions: concern about one's vocational future, perceived control on the shaping of one's future career, curiosity about self and career opportunities, and confidence in one's capacity to overcome vocational barriers. Higher levels of career adaptability are associated with positive STWT processes and outcomes such as job-searching effectiveness (Guan et al., 2014; Koen et al., 2014), a clear vocational identity (Porfeli \& Savickas, 2012), and students' self-efficacy (Duffy et al., 2015).

Self-efficacy. Conceived as individuals' beliefs in their abilities to master certain tasks (Bandura, 1986), self-efficacy is among the most investigated psychosocial variables in relation with the STWT $(\mathrm{Ng} \&$ Feldman, 2007). It can be general or domain-specific, indicating one's efficacy beliefs to perform well in various domains such as academic, occupational, decision making, and job search (Guan et al., 2014). Research has demonstrated the role of these beliefs as predictors of the success of STWT (Lent et al., 1999). For example, Pinquart et al. (2003) showed that high academic self-efficacy at the ages of $12-15$ predicts higher job satisfaction and lower chances to be unemployed at 21 years. Also, job search self-efficacy increases the probability to find a job after university graduation (Guan et al., 2014). Finally, Swiss adolescents reporting high occupational self-efficacy were more likely to avoid "hangover" patterns - that is, a decline in job satisfaction — during the first months of vocational training (Valero \& Hirschi, 2019); in addition, they demonstrated a clear vocational identity, which in turn facilitated their transition from compulsory education to vocational education and training (VET; Steiner et al., 2019).

Career adaptability and self-efficacy are interrelated, mainly when considering self-efficacy within the occupational domain. For example, Duffy et al. (2015) showed that adaptability dimensions predicted career decision self-efficacy of undergraduate students. Moreover, far from being unequivocal individual characteristics, these resources are influenced by contextual, social, and psychological factors. For example, Bandura et al. (2001) show that family socioeconomic status impacts parents' selfefficacy beliefs, which in turn influence children's perceived self-efficacy and, subsequently, their academic aspirations and career trajectories. Furthermore, studies show that adaptability resources are also influenced by family support (Johnston, 2018) and social status (Autin et al., 2017).

\section{Identity}

The sense of identity is another specific mediator in the STWT process. From a developmental perspective, identity is indeed a critical task for emerging adults who transition from school to work (Grosemans et al., 2018; Porfeli et al., 2013). Young adults' identity issues in their effort to choose an occupation and take their place in the world of work are well-investigated psychosocial processes within the STWT literature (Dietrich et al., 2012; Grosemans et al., 2018; Ng \& Feldman, 2007; Skorikov \& Vondracek, 2011). Identity plays a key mediator role between contextual predictors and the quality of the STWT through two main processes: the formation of a vocational identity that leads to the choice of an occupation and the development of a role identity as a worker $(\mathrm{Ng} \&$ Feldman, 2007). 
Vocational identity. Vocational identity "reflects knowledge regarding stable patterns of career interests, goals, and abilities" (Gupta et al., 2015, p. 79). It develops through interaction processes between the self and occupational options in terms of exploration-commitment-reconsideration and stems from psychological (e.g., interests, values, personal goals), psychosocial (e.g., self-efficacy, agency), and contextual (e.g., affordances, experiences) influences (Porfeli et al., 2013). Research conducted within the last 30 years shows that a strong vocational identity has positive effects on STWT and on career development (Skorikov \& Vondracek, 2011). Indeed, young adults' clear self-knowledge facilitates the identification of the most appropriate career options, which in turn predicts their future occupational integration (Gupta et al., 2015; Steiner et al., 2019). Moreover, research shows that a clear vocational identity predicts effective enrollment in VET after compulsory school (Steiner et al., 2019), whereas an unclear vocational identity might lead to a higher risk of experiencing disillusion when entering the world of work (Grosemans et al., 2018).

Work role identity. Transitioning from school to work also implies the readiness to switch roles from a student to a worker (Medvide et al., 2019; Ng \& Feldman, 2007). This second process refers to the construction of a work role identity, defined as "the salience of an individual's participation and commitment to working relative to other life roles and the extent to which an individual can express his/her values through work" (Ng \& Feldman, 2007, p. 117). A study on unemployed young adults shows that the development of a positive work role identity facilitates their transition toward employment, even when their career plans are vague (Koen et al., 2016). This perspective also stresses the importance of understanding the attitudes of young adults toward work and, more generally, the meaning they attribute to the work sphere in their lives (Masdonati \& Fournier, 2015).

It appears that identity is related with the other mediators of the STWT since "those more adaptable tend to have a more established vocational identity and feel more confident making career decisions" (Duffy et al., 2016, p. 136). Moreover, the role of identity as a mediator between the STWT predictors and the transition success is empirically verified. For example, Holtmann et al. (2017) showed that low-achieving pupils searching for a VET position reported higher agency when they had high aspirations, clear career plans, and a good vocational orientation, all factors that contribute to a clear vocational identity.

\section{Moderators}

In the model, we posit specific variables that can boost or buffer the strength of the relation between predictors and outcomes of STWT. These include contextual/environmental factors like education system, labor market conditions, and social support as well as individual factors such as critical consciousness. When compared with PWT, our model corroborates the importance of social support and economic conditions (in our case, labor market conditions). Moreover, we added education system as a key moderator factor. Finally, we removed proactive personality since the influence of personality factors on the STWT is not clearly highlighted and that literature stresses that personality might change during emerging adulthood (e.g., Hopwood et al., 2011).

\section{Education Systems}

The characteristics of the education system play a pivotal role in the STWT process because it provides qualifications, which in turn impact transition outcomes (Akkermans et al., 2015). Future career paths and employment stability of students are thus highly influenced by the education system they are enrolled in (Ilieva-Trichkova \& Boyadjieva, 2018; Imdorf et al., 2015). More particularly, two key dimensions of the education system exert a significant influence on students' coping with this 
transitional challenge: the degree of inclusiveness and the type of "transition regime" (Schoon \& Heckhausen, 2019).

Education systems present different degrees of inclusiveness, depending on their structures and rules (Schoon \& Heckhausen, 2019). In the most inclusive systems, the goal is to maintain all students in a common track, as long as possible and independent of their performances. Alternatively, students are also offered opportunities to change tracks and advance at their own pace without being penalized. In contrast, other systems are highly selective and differentiated, directing students - often quite soon in their academic trajectory-toward specific and distinct tracks based on their grades. In such systems, tracks are less permeable and more hierarchical, bringing young adults in lower educational tracks to be clearly labeled as underperforming. Finally, the less inclusive systems are those producing high rates of school leavers and so-called work-bound youths (Schoon \& Heckhausen, 2019).

Education systems are also characterized by their transition regime, based on the timing and the smoothness of the STWT (Schoon \& Heckhausen, 2019). In other words, the STWT can occur at a more or less young age and represent a more or less abrupt change, depending on certain "institutional arrangements" (Schoon \& Heckhausen, 2019, p. 140). The part played by VET and its recognition as a valued and viable track within the system seems to be important here (Akkermans et al., 2015; Schoon \& Heckhausen, 2019). In countries with a strong and widespread VET tradition (e.g., Germany or Switzerland), the STWT occurs already at the end of adolescence for a majority of students, whereas in countries with a strong accent on tertiary education, the transition mainly occurs during emerging adulthood. One could assume that "the later the better," arguing that the smaller gap between emerging adults and their coworkers demands less efforts in terms of adaptation and socialization. However, it also appears that in systems where the majority follows the college-university path, work-bound youth represent a vulnerable group with higher risk of experiencing precarious transitions (Blustein et al., 2002; Vuolo et al., 2014). Beyond timing issues, the smoothness of the STWT also affects its success. Indeed, young adults in transition face high demands and challenges in terms of on-the-job learning and integration efforts (Saks, 2018). Therefore, the STWT could be experienced as less sudden when a progressive preparation for job integration is implemented during the last years of education $(\mathrm{Ng} \&$ Feldman, 2007; Saks, 2018).

Within our model, the education system is thought to mainly moderate the impact of educational attainment and socioeconomic status on the success of STWT (Blustein et al., 2002; Schoon \& Heckhausen, 2019). Given the influence of socioeconomic factors on school performance, education systems with a strong accent on grade-based selection leading to differentiated tracks and an early occurring transition to employment tend to exacerbate social inequalities and constrain individual agency in the STWT (Blustein et al., 2002; Schoon \& Heckhausen, 2019). In contrast, contextual disadvantages are buffered in more inclusive systems leading to deferred or progressive STWTs (OECD, 2010). The school system also moderates the relation between gender and the STWT outcomes. The association between gender segregation and the education system is indeed noteworthy: Gender-typed tracks and choices are most salient when the STWT takes place at a younger age through VET, whereas gender inequalities are low in countries where the transition occurs after higher education (Imdorf et al., 2015). However, in systems with a main focus on tertiary education, young women without a college degree encounter more difficulties to attain autonomy and economic stability than young men do (Danziger \& Ratner, 2010).

\section{Labor Market Conditions}

PWT suggests that economic conditions moderate the likelihood of accessing decent work (Duffy et al., 2016). In a similar way, the state of the labor market young adults face when leaving school influences the fluidity of their STWT, with poor labor market conditions aggravating the effects of contextual determinants on their chances of successfully attaining employment (Masdonati \& 
Fournier, 2015). Research on the 2007/2008 Great Recession confirms this pattern, showing that adverse economic conditions affected young workers more than others. Moreover, the recession also reinforced the impact of educational attainment and transition regimes on the success of the transition (Danziger \& Ratner, 2010; Schoon \& Heckhausen, 2019; Vuolo et al., 2014), thus exacerbating the difficulties and barriers faced by underprivileged youth (Perez-Brena et al., 2017).

\section{Critical Consciousness}

Critical consciousness of disadvantaged young adults (i.e., their capacity to confront oppressive social conditions and inequalities) is receiving increased attention in the field of vocational psychology (e.g., Kenny et al., 2019). According to Diemer et al. (2016), this capacity is composed of three elements: critical reflection, motivation, and action. Recent research in the United States on ethnic minorities with low socioeconomic status shows that high levels of critical consciousness are associated with positive educational and work outcomes such as career development (McWhirter \& McWhirter, 2016), occupational attainment (Diemer, 2009), and work salience and expectations (Diemer et al., 2010). Critical consciousness seems indeed to moderate the impact of contextual factors on some outcomes of the STWT, by attenuating the disadvantages of ethnically marginalized groups and youth with low socioeconomic status, hence enabling their social mobility (Diemer et al., 2010).

\section{Social Support}

Social support is a resource regarding diverse career issues and challenges, such as access to decent work (Duffy et al., 2016; Kenny \& Medvide, 2013). It can take multiple forms such as emotional support, social integration and networking facilitation, protection of the self-esteem, provision of information, or tangible and instrumental support (Schultheiss et al., 2001). Perceived support from friends, family members, romantic partners, professionals, or coworkers plays a facilitating role specifically in the STWT process, before, during, and after the passage from education to employment (Dietrich et al., 2012; Medvide et al., 2019; Ng \& Feldman, 2007). Before leaving school, supportive environments may enhance students' work expectations (Murphy et al., 2010) and occupational exploration (Buhl et al., 2018). During the job search phase, family support helps to persevere despite difficulties and instability (Hardgrove et al., 2015). Once in employment or training, support from coworkers and supervisors reduces the risk of a hangover effect when entering VET (Valero \& Hirschi, 2019). Finally, assistance from career counselors or mentors can also be beneficial to youth engaged in STWT (Kenny et al., 2019; Renn et al., 2014).

It appears then that social support moderates the relation between contextual and psychosocial factors, and the STWT success in multiple ways. For example, social support seems to facilitate the development of young adults' vocational identity by encouraging their occupational exploration (Buhl et al., 2018). Furthermore, social support from professionals exerts a positive influence on young adults' career and occupational self-efficacy (Renn et al., 2014; Valero \& Hirschi, 2019).

\section{Outcomes}

Our model posits that the positive outcomes of a successful STWT are twofold. First, a favorable transition should give access to jobs that offer objectively decent working conditions and perspectives. Second, positive outcomes should also lead to employment positions that are subjectively meaningful.

\section{Decent Work}

The definition of decent work is generally inspired by the guidelines of the ILO (2013), which advocates for access to full and just employment conditions for all while benefiting from social protection 
and social dialogue at work. Based on the ILO guidelines, the PWT highlights five characteristics of decent work (Duffy et al., 2017). In this perspective, decent work should (1) guarantee working conditions that are physically, emotionally, and interpersonally safe, (2) allow access to healthcare, especially in countries where health protections depend on the workplace, (3) offer adequate compensation through a salary that reflects workers' qualifications, experiences, and efforts, (4) provide workers with enough free time and moments of rest, so they can engage in nonwork activities, and (5) promote values that match or complement those of the workers' family and community. In addition to these indicators, one should also highlight more distal STWT outcomes in terms of resources to alleviate career instability and job insecurity (Urbanavičiūte et al., 2015). In their research on Canadian workers, Krahn et al. (2015) showed, for example, that early employment instability (19-25 years) negatively predicted further income, occupational status, and career satisfaction. Even though temporary contracts are common when it comes to a first job, successful STWT should at least lead to a midto long-term opportunity of permanent contract and employment guaranty (Ling \& O'Brien, 2013).

\section{Meaningful Work}

Beyond these indicators that point at objective working and employment conditions, authors in the field of vocational psychology also highlight the importance of the subjective meaning attributed to work (Blustein et al., 2016; Fournier et al., 2019; Massoudi et al., 2018). For example, in a research conducted in seven developed and developing countries on low-qualified young workers, participants stressed that work should not only offer good pay and working conditions but also purposeful and enjoyable contents as well as opportunities for socialization (Cohen-Scali et al., 2020). In line with these findings, we consider access to meaningful jobs as the second significant outcome of a successful STWT. Indeed, meaningful jobs reflect the importance of the professional sphere in people's lives, lead to the attainment of valued goals, and fulfill the purposes that they attribute to work (SheaVan Fossen \& Vredenburgh, 2014). Furthermore, it also appears that meaningful work responds to young workers' need to feel socially integrated in the organization and foster a sense of belongingness to an occupational group. Indeed, research on organizational socialization shows that social recognition and integration enhance newcomers' adjustment (Saks et al., 2007), organizational commitment, and task mastery (Nägele \& Neuenschwander, 2014).

\section{Discussion}

In this article, we used a multidisciplinary lens, inspired by PWT (Blustein, 2006, 2013; Duffy et al., 2016), to examine and contextualize the STWT process. First, the proposed model highlights the key role of contextual factors as predictors of the STWT outcomes. Indeed, disadvantages deriving from social background or marginalization hinder a smooth entrance into the labor market. Second, psychosocial factors also influence the STWT, putting at-risk young adults who lack self-efficacy and career adaptability, or have an inaccurate work role and vocational identity. Third, the inherent characteristics of the education system young adults are enrolled in, the actual conditions of the labor market they face, the support they can rely on, and their level of critical consciousness are proposed as the main moderators of the impact of the predictors on the STWT. Fourth, there is more to the STWT than merely finding a job after school. A successful STWT implies finding a position in adequacy with one's education and maintaining a high level of employability. Fifth, in the mid- to long-long-term perspective, a successful STWT should lead to decent and meaningful work and sustained career prospects.

The adaptation of PWT to the STWT reveals recurrent themes and transversal factors inherent to the experience of work. It also highlights aspects that seem specific to the first steps in the career development process. Indeed, both PWT and the STWT model stress the crucial role of social/contextual 
determinants and the mediating role of psychosocial factors when trying to understand people's striving for professional integration and fulfillment, thus revealing the limits of a solely psychological approach. Both models also posit similar outcomes: A successful STWT should lead to decent and meaningful work, which are core features of PWT. However, because the STWT mainly concerns young adults, identity processes seem more crucial here than when considering adult workers. Moreover, while PWT implies the influence of education without addressing it directly, our model highlights the mechanisms through which the education system exacerbates or attenuates inequalities and exclusion dynamics when it comes to the STWT.

\section{Limitations and Research and Theory Perspectives}

The suggested model of the STWT entails some limits that should be addressed in future research and theoretical contributions. First, if some relations among the selected variables are distinctly stressed, the influence of other variables is less clear. Particularly, a finer analysis of the mediators is needed to better grasp the underlying processes through which their influence occurs. For example, research should further investigate through which processes vocational and work role identities develop and what hinders such development. Second, far from being exhaustive, our model highlights a selection of key factors impacting the STWT. Other potentially important individual (e.g., personality traits or skills) and contextual factors (e.g., other marginalized groups) would merit further attention. Third, our model remains rather general and draws on research carried out in diverse contexts (e.g., Canada, Switzerland, the UK, and the United States). Social, cultural, and economic specificities should be taken into account for a better adaptation of the model.

Nevertheless, this article is one of the rare recent attempts to integrate inputs from a variety of disciplines and propose a complete picture of the STWT challenges within the contemporary socioeconomic context. Such a multidisciplinary effort should be pursued to include findings from other fields such as rehabilitation, cross-cultural, or sexual minority studies, in order to address the specific challenges faced by particular groups or communities (e.g., Chen \& Keats, 2016; Nilsson, 2019). To conclude, we would like to stress the need for longitudinal and multimethod investigations of the STWT. In this sense, quantitative studies could test the causal relations between the model's factors, whereas qualitative research could explore underlying processes and the challenges experienced by vulnerable populations. A promising perspective here would consist of fostering theory and research connections between STWT and recent approaches of sustainability within the career domain. Indeed, recent notions such as sustainable start (Blokker et al., 2019) or sustainable career (De Vos et al., 2018) could contribute to the reflection on successful STWT.

\section{Implications for Practice}

The implications of our reflections for career counseling practices can be situated at the macro-social, micro-social, and individual levels (Medvide et al., 2019). Macro-level interventions seem crucial to alleviate the adverse contextual and institutional influences. As privileged witnesses of the challenges and barriers faced by young people in transition, career counselors could convey useful information to policy makers and school representatives to promote inclusive educational paths. Career counselors can also use their awareness to elaborate and implement effective interventions responding to the needs of marginalized or excluded populations, in order to reduce inequalities, and promote smooth and decent STWTs for all (Kozan \& Blustein, 2018). At a micro-social level, interventions aiming to prevent school dropout are also crucial to ensure a sufficient - at least upper secondary-level of school attainment for the greatest possible number of young people (OECD, 2017). Additionally, research also shows the efficacy of group interventions to foster social support and networking or school-based career training programs to help students prepare for the STWT (e.g., Akkermans 
et al., 2015; Koen et al., 2014). Furthermore, interventions aiming to foster students' purpose and critical consciousness may also represent promising avenues (e.g., Kenny et al., 2019). Work-based programs are also helpful by providing students with an opportunity to build a realistic view of the world of work and accumulate work experiences that protect them from floundering STWTs (OECD, 2010; Vuolo et al., 2014). Through such interventions, young people can indeed anticipate the changes to come and reduce the risk of reality shocks when entering the labor market (Ling \& O'Brien, 2013; Ng \& Feldman, 2007).

\section{Conclusion}

According to the ILO (2019),

we are counting on youth to lead us into a future of sustainable development and decent work, but achieving these goals requires that we first ensure that youth around the world have adequate access to education and training and to the labour market. (p. 1)

Understanding how the contemporary world of work has affected the STWT is crucial to identify risks of chaotic transitions and prevent the long-lasting impacts of a poor start on people's life course. The theoretical model proposed stresses the strong influence of contextual predictors on the chances of experiencing a successful transition and, consequently, attaining decent and meaningful work. We claim the pertinence and necessity to pursue the development of a multidisciplinary, overarching and critical perspective to better understand the complexity of the STWT. Such an understanding should contribute to counseling practices that take systematically into account contextual determinants of careers, advocate for more inclusive institutions, and identify ways to alleviate social inequalities.

\section{Declaration of Conflicting Interests}

The authors declared no potential conflicts of interest with respect to the research, authorship, and/or publication of this article.

\section{Funding}

The authors received no financial support for the research, authorship, and/or publication of this article.

\section{ORCID iD}

Jonas Masdonati (D) https://orcid.org/0000-0002-1897-1425

\section{References}

Akkermans, J., Nykänen, M., \& Vuori, J. (2015). Practice makes perfect? Antecedents and consequences of an adaptive school-to-work transition. In J. Vuori, R. Blonk, \& R. H. Price (Eds.), Sustainable working lives: Managing work transitions and health throughout the life course (pp. 65-86). Springer. https://doi.org/10. 1007/978-94-017-9798-65

Ali, S. R., \& Menke, K. A. (2014). Rural Latino youth career development: An application of social cognitive career theory. The Career Development Quarterly, 62, 175-186. https://doi.org/10.1002/j.2161-0045.2014. 00078.x

Autin, K. L., Douglass, R. P., Duffy, R. D., England, J. W., \& Allan, B. A. (2017). Subjective social status, work volition, and career adaptability: A longitudinal study. Journal of Vocational Behavior, 99, 1-10. https://doi.o $\mathrm{rg} / 10.1016 /$ j.jvb.2016.11.007

Bandura, A. (1986). Social foundations of thought and action: A social cognitive theory. Prentice Hall. 
Bandura, A., Barbaranelli, C., Caprara, G. V., \& Pastorelli, C. (2001). Self-efficacy beliefs as shapers of children's aspirations and career trajectories. Child Development, 72, 187-206. https://doi.org/10.1111/1467-8624.00273

Blokker, R., Akkermans, J., Tims, M., Jansen, P., \& Khapova, S. (2019). Building a sustainable start: The role of career competencies, career success, and career shocks in young professionals' employability. Journal of Vocational Behavior, 112, 172-184. https://doi.org/10.1016/j.jvb.2019.02.013

Blustein, D. L. (2006). The psychology of working: A new perspective for career development, counseling, and public policy. Routledge.

Blustein, D. L. (2013). The psychology of working: A new perspective for a new era. In D. L. Blustein (Ed.), The Oxford handbook of the psychology of working (pp. 3-18). Oxford University Press. https://doi.org/10.1093/o xfordhb/9780199758791.013.0001

Blustein, D. L., Chaves, A. P., Diemer, M. A., Gallagher, L. A., Marshall, K. G., Sirin, S., \& Bhati, K. S. (2002). Voices of the forgotten half: The role of social class in the school-to-work transition. Journal of Counseling Psychology, 49, 311-323. https://doi.org/10.1037//0022-0167.49.3.311

Blustein, D. L., Olle, C., Connors-Kellgren, A., \& Diamonti, A. J. (2016). Decent work: A psychological perspective. Frontiers in Psychology, 7, 407. https://doi.org/10.3389/fpsyg.2016.00407

Buhl, H. M., Noack, P., \& Kracke, B. (2018). The role of parents and peers in the transition from university to work life. Journal of Career Development, 45, 523-535. https://doi.org/10.1177/0894845317720728

Bynner, J., \& Parsons, S. (2002). Social exclusion and the transition from school to work: The case of young people not in education, employment, or training (NEET). Journal of Vocational Behavior, 60, 289-309. https:// doi.org/10.1006/jvbe.2001.1868

Chen, C. P., \& Keats, A. (2016). Career development and counselling needs of LGBTQ high school students. British Journal of Guidance \& Counselling, 44, 576-588. https://doi.org/10.1080/03069885.2016.1187709

Cohen-Scali, V., Masdonati, J., Disquay-Perrot, S., Ribeiro, M. A., Vilhjálmsdóttir, G., Zein, R., Kaplan-Bucciarelli, J., Moumoula, I., Aisenson, G., \& Rossier, J. (2020). Emerging adults' representations of work: A qualitative research in seven countries. Emerging Adulthood. Advance online publication. https://doi.org/10.1177/ 2167696820963598

Danziger, S., \& Ratner, D. (2010). Labor market outcomes and the transition to adulthood. The Future of Children, 20, 133-158. https://doi.org/10.1353/foc. 0.0041

De Vos, A., Van der Heijden, B. I. J. M., \& Akkermans, J. (2018). Sustainable careers: Toward a conceptual model. Journal of Vocational Behavior. Advance online publication. https://doi.org/10.1016/j.jvb.2018.06.011

Diemer, M. A. (2009). Pathways to occupational attainment among poor youth of color: The role of sociopolitical development. The Counseling Psychologist, 37, 6-35. https://doi.org/10.1177/0011000007309858

Diemer, M. A., Rapa, L. J., Voight, A. M., \& McWhirter, E. H. (2016). Critical consciousness: A developmental approach to addressing marginalization and oppression. Child Development Perspectives, 10, 216-221. https:// doi.org/10.1111/cdep.12193

Diemer, M. A., Wang, Q., Moore, T., Gregory, S. R., Hatcher, K. M., \& Voight, A. M. (2010). Sociopolitical development, work salience, and vocational expectations among low socioeconomic status African American, Latin American, and Asian American youth. Developmental Psychology, 46, 619-635. https://doi.org/10.103 7/a0017049

Dietrich, J., Parker, P., \& Salmela-Aro, K. (2012). Phase-adequate engagement at the post-school transition. Developmental Psychology, 48, 1575-1593. https://doi.org/10.1037/a0030188

Duffy, R. D., Allan, B. A., England, J. W., Blustein, D. L., Autin, K. L., Douglass, R. P., Ferreira, J., \& Santos, E. J. R. (2017). The development and initial validation of the decent work scale. Journal of Counseling Psychology, 64, 206-221. https://doi.org/10.1037/cou0000191

Duffy, R. D., Blustein, D. L., Diemer, M. A., \& Autin, K. L. (2016). The Psychology of Working Theory. Journal of Counseling Psychology, 63, 127-148. https://doi.org/10.1037/cou0000140

Duffy, R. D., Douglass, R. P., \& Autin, K. L. (2015). Career adaptability and academic satisfaction: Examining work volition and self-efficacy as mediators. Journal of Vocational Behavior, 90, 46-54. https://doi.org/10. 1016/j.jvb.2015.07.007 
Feldman, D. (2004). The role of physical disabilities in early career: Vocational choice, the school-to-work transition and becoming established. Human Resource Management Review, 14, 247-274. https://doi.org/10.1016/j. hrmr.2004.06.002

Forrier, A., De Cuyper, N., \& Akkermans, J. (2018). The winner takes it all, the loser has to fall: Provoking the agency perspective in employability research. Human Resource Management Journal, 28, 511-523. https:// doi.org/10.1111/1748-8583.12206

Fournier, G., Lachance, L., Viviers, S., Lahrizi, I. Z., Goyer, L., \& Masdonati, J. (2019). Development and initial validation of a multidimensional questionnaire on the relationship to work (RWQ). International Journal for Educational and Vocational Guidance. Advance online publication. https://doi.org/10.1007/s10775-019-093 97-0

Grosemans, I., Hannes, K., Neyens, J., \& Kyndt, E. (2018). Emerging adults embarking on their careers: Job and identity explorations in the transition to work. Youth \& Society. Advance online publication. https://doi.org/10. 1177/0044118X18772695

Guan, Y., Guo, Y., Bond, M. H., Cai, Z., Zhou, X., Xu, J., Zhu, F., Wang, Z., Fu, R., Liu, S., Wang, Y., Hu, T., \& Ye, L. (2014). New job market entrants' future work self, career adaptability and job search outcomes: Examining mediating and moderating models. Journal of Vocational Behavior, 85, 136-145. https://doi.org/10. 1016/j.jvb.2014.05.003

Gupta, A., Chong, S., \& Leong, F. T. L. (2015). Development and validation of the vocational identity measure. Journal of Career Assessment, 23, 79-90. https://doi.org/10.1177/1069072714523088

Hardgrove, A., McDowell, L., \& Rootham, E. (2015). Precarious lives, precarious labour: Family support and young men's transitions to work in the UK. Journal of Youth Studies, 18, 1057-1076. https://doi.org/10. 1080/13676261.2015.1020933

Holtmann, A. C., Menze, L., \& Solga, H. (2017). Persistent disadvantages or new opportunities? The role of agency and structural constraints for low-achieving adolescents' school-to-work transitions. Journal of Youth and Adolescence, 46, 2091-2113. https://doi.org/10.1007/s10964-017-0719-z

Hopwood, C. J., Donnellan, M. B., Blonigen, D. M., Krueger, R. F., McGue, M., Iacono, W. G., \& Burt, S. A. (2011). Genetic and environmental influences on personality trait stability and growth during the transition to adulthood: A three-wave longitudinal study. Journal of Personality and Social Psychology, 100, 545-556. https://doi.org/10. 1037/a0022409

Ilieva-Trichkova, P., \& Boyadjieva, P. (2018). Educational systems matter: Differences across European countries in how young people with secondary education experience job insecurity. Journal of Education and Work, 31, 595-610. https://doi.org/10.1080/13639080.2018.1559281

Imdorf, C., Hegna, K., Eberhard, V., \& Doray, P. (2015). Educational systems and gender segregation in education: A three-country comparison of Germany, Norway and Canada. In C. Imdorf, K. Hegna, \& L. Reisel (Eds.), Gender segregation in vocational education (pp. 83-122). Emerald Group Publishing.

International Labor Organization. (2013). Decent work indicators: Guidelines for procedures and users of statistical and legal framework indicators (2nd ed.). International Labor Office. http://www.ilo.org/wcmsp5/gro ups/public/_dgreports/_integration/documents/publication/wcms_229374.pdf

International Labor Organization. (2019). Labour market access-A persistent challenge for youth around the world: A study based on ILO's global estimates for youth labour market indicators. ILOSTAT Spotlights on Work Statistics, 5. chttps://ilo.org/wcmsp5/groups/public/—dgreports/—stat/documents/publication/ wcms_676196.pdf

Johnston, C. S. (2018). A systematic review of the career adaptability literature and future outlook. Journal of Career Assessment, 26, 3-30. https://doi.org/10.1177/1069072716679921

Kenny, M. E., Blustein, D. L., Liang, B., Klein, T., \& Etchie, Q. (2019). Applying the psychology of working theory for transformative career education. Journal of Career Development, 46, 623-636. https://doi.org/10. $1177 / 0894845319827655$ 
Kenny, M. E., \& Medvide, M. B. (2013). Relational influences on career development. In S. D. Brown \& R. W. Lent (Eds.), Career development and counseling: Putting theory and research to work (2nd ed., pp. 329-356). John Wiley.

Kim, T., \& Allan, B. A. (2019). Underemployment and meaningful work: The role of psychological needs. Journal of Career Assessment, 28, 76-90. https://doi.org/10.1177/1069072718824004

Koen, J., Klehe, U.-C., \& Van Vianen, A. (2014). Training career adaptability to facilitate a successful school-towork transition. Journal of Vocational Behavior, 81, 395-408. https://doi.org/10.1016/j.jvb.2012.10.003

Koen, J., Van Vianen, A., Klehe, U.-C., \& Zikic, J. (2016). "A whole new future"-Identity construction among disadvantaged young adults. Career Development International, 7, 658-681. https://doi.org/10.1108/CDI-022016-0019

Kozan, S., \& Blustein, D. L. (2018). Implementing social change: A qualitative analysis of counseling psychologists' engagement in advocacy. The Counseling Psychologist, 46, 154-189. https://doi.org/10.1177/ 0011000018756882

Krahn, H. J., Howard, A. L., \& Galambos, N. L. (2015). Exploring or floundering? The meaning of employment and educational fluctuations in emerging adulthood. Youth \& Society, 47, 245-266. https://doi.org/10.1177/ 0044118X12459061

Lent, R. W., Hackett, G., \& Brown, S. D. (1999). A social cognitive view of school-to-work transition. The Career Development Quarterly, 47, 297-311. https://doi.org/10.1002/j.2161-0045.1999.tb00739.x

Lent, R. W., \& Worthington, R. L. (1999). Applying career development theories to the school-to-work transition process. The Career Development Quarterly, 47, 291-296. https://doi.org/10.1002/j.2161-0045.1999. tb00738.x

Ling, T. J., \& O’Brien, K. M. (2013). Connecting the forgotten half: The school-to-work transition of noncollegebound youth. Journal of Career Development, 40, 347-367. https://doi.org/10.1177/0894845312455506

Marshall, S. K., Young, R. A., Stevens, A., Spence, W., Deyell, S., Easterbrook, A., \& Brokenleg, M. (2011). Adolescent career development in urban-residing aboriginal families in Canada. The Career Development Quarterly, 59, 539-558. https://doi.org/10.1002/j.2161-0045.2011.tb00975.x

Masdonati, J., \& Fournier, G. (2015). Life design, young adults, and the school-to-work transition. In L. Nota \& J. Rossier (Eds.), Handbook of the Life Design paradigm: From practice to theory and from theory to practice (pp. 117-133). Hogrefe Publishing.

Massoudi, K., Abessolo, M., Atitsogbe, K. A., Banet, E., Bollmann, G., Dauwalder, J.-P., Handschin, P., Maggiori, C., Masdonati, J., Rochat, S., \& Rossier, J. (2018). A value-centered approach to decent work. In V. Cohen-Scali, J. Pouyaud, M. Podgórny, V. Drabik-Podgórna, G. Aisenson, J.-L. Bernaud, I. A. Moumoula, \& J. Guichard (Eds.), Interventions in career design and education: Transformation for sustainable development and decent work (pp. 93-110). Springer.

McWhirter, E. H., \& McWhirter, B. T. (2016). Critical consciousness and vocational development among Latina/ o high school youth: Initial development and testing of a measure. Journal of Career Assessment, 24, 543-558. https://doi.org/10.1177/1069072715599535

Medvide, M. B., Kozan, S., Blustein, D. L., \& Kenny, M. E. (2019). School to work transition of non-college bound youth: An integration of the Life Design paradigm and the Psychology of Working Theory. In J. G. Maree (Ed.), Handbook of innovative career counselling (pp. 157-172). Springer. https://doi.org/10.1007/ 978-3-030-22799-9_10

Murphy, K. A., Blustein, D. L., Bohlig, A. J., \& Platt, M. G. (2010). The college-to-career transition: An exploration of emerging adulthood. Journal of Counseling \& Development, 88, 174-181. https://doi.org/10.1002/j. 1556-6678.2010.tb00006.x

Nägele, C., \& Neuenschwander, M. P. (2014). Adjustment processes and fit perceptions as predictors of organizational commitment and occupational commitment of young workers. Journal of Vocational Behavior, 85, 385-393. https://doi.org/10.1016/j.jvb.2014.08.011

Ng, W. H. T., \& Feldman, D. C. (2007). The school-to-work transition: A role identity perspective. Journal of Vocational Behavior, 71, 114-134. https://doi.org/10.1016/j.jvb.2007.04.004 
Ng-Knight, T., \& Schoon, I. (2017). Can locus of control compensate for socioeconomic adversity in the transition from school to work? Journal of Youth and Adolescence, 46, 2114-2128. https://doi.org/10.1007/s10964-0170720-6

Nilsson, B. (2019). The school-to-work transition in developing countries. The Journal of Development Studies, 55, 745-764. https://doi.org/10.1080/00220388.2018.1475649

Organization for Economic Co-operation and Development. (2010). Off to a good start? Jobs for youth. OECD Publishing. https://doi.org/10.1787/9789264096127-en

Organization for Economic Co-operation and Development. (2016). Education at a glance 2016: OECD indicators. OECD Publishing. https://doi.org/10.1787/eag-2016-en

Organization for Economic Co-operation and Development. (2017). Transition from school to work: How hard is it across different age groups? Education Indicators in Focus, No. 54. OECD Publishing. https://doi.org/10. 1787/1e604198-en

Peeters, E., Nelissen, J., De Cuyper, N., Forrier, A., Verbruggen, M., \& De Witte, H. (2019). Employability capital: A conceptual framework tested through expert analysis. Journal of Career Development, 46, 79-93. https://doi.org/10.1177/0894845317731865

Perez-Brena, N. J., Wheeler, L. A., De Jesús, S. A. R., Updegraff, K. A., \& Umaña-Taylor, A. J. (2017). The educational and career adjustment of Mexican-origin youth in the context of the 2007/2008 economic recession. Journal of Vocational Behavior, 100, 149-163. https://doi.org/10.1016/j.jvb.2017.02.006

Pinquart, M., Juang, L. P., \& Silbereisen, R. K. (2003). Self-efficacy and successful school-to-work transition: A longitudinal study. Journal of Vocational Behavior, 63, 329-346. https://doi.org/10.1016/S00018791(02)00031-3

Porfeli, E. J., Lee, B., \& Vondracek, F. W. (2013). Identity development and careers in adolescents and emerging adults: Content, process, and structure. In W. B. Walsh, M. L. Savickas, \& P. J. Hartung (Eds.), Handbook of vocational psychology: Theory, research, and practice (4th ed., pp. 133-153). Routledge.

Porfeli, E. J., \& Savickas, M. L. (2012). Career Adapt-Abilities Scale-USA form: Psychometric properties and relation to vocational identity. Journal of Vocational Behavior, 80, 748-753. https://doi.org/10.1016/j.jvb.2012.01.009

Renn, R. W., Steinbauer, R., Taylor, R., \& Detwiler, D. (2014). School-to-work transition: Mentor career support and student career planning, job search intentions, and self-defeating job search behavior. Journal of Vocational Behavior, 85(3), 422-432. https://doi.org/10.1016/j.jvb.2014.09.004

Rojewski, J. W., \& Kim, H. (2003). Career choice patterns and behavior of work-bound youth during early adolescence. Journal of Career Development, 30, 89-108. https://doi.org/10.1023/A:1026150427009

Saks, A. M. (2018). Job search and the school-to-work transition. In U.-C. Klehe \& E. van Hooft (Eds.), The Oxford handbook of job loss and job search (pp. 1-36). Oxford University Press. https://doi.org/10.1093/o xfordhb/9780199764921.013.008

Saks, A. M., Uggerslev, K. L., \& Fassina, N. E. (2007). Socialization tactics and newcomer adjustment: A metaanalytic review and test of a model. Journal of Vocational Behavior, 70, 413-446. https://doi.org/10.1016/j. jvb.2006.12.004

Savickas, M. L., \& Porfeli, E. J. (2012). Career Adapt-Abilities Scale: Construction, reliability, and measurement equivalence across 13 countries. Journal of Vocational Behavior, 80, 661-673. https://doi.org/10.1016/j.jvb. 2012.01.011

Schoon, I., \& Heckhausen, J. (2019). Conceptualizing individual agency in the transition from school to work: A social-ecological developmental perspective. Adolescent Research Review, 4, 135-148. https://doi.org/10. 1007/s40894-019-00111-3

Schoon, I., \& Polek, E. (2011). Teenage career aspirations and adult career attainment: The role of gender, social background and general cognitive ability. International Journal of Behavioral Development, 35, 210-217. https://doi.org/10.1177/0165025411398183 
Schoon, I., \& Silbereisen, R. K. (2009). Conceptualizing school-to-work transitions in context. In I. Schoon \& R. K. Silbereisen (Eds.), Transitions from school to work: Globalization, individualization, and patterns of diversity (pp. 3-29). Cambridge University Press.

Schultheiss, D. E., Kress, H. M., Manzi, A. J., \& Glasscock, J. M. (2001). Relational influences in career development: A qualitative inquiry. The Counseling Psychologist, 29, 216-241. https://doi.org/10.117710011000001292003

Shea-Van Fossen, R. J., \& Vredenburgh, D. J. (2014). Exploring differences in work's meaning: An investigation of individual attributes associated with work orientations. Journal of Behavioral and Applied Management, 15(2), 101-120.

Skorikov, V. B., \& Vondracek, F. W. (2011). Occupational identity. In S. J. Schwartz, K. Luyckx, \& V. L. Vignoles (Eds.), Handbook of identity theory and research (pp. 693-714). Springer. https://doi.org/10.1007/978-1-44197988-929

Steiner, R. S., Hirschi, A., \& Wang, M. (2019). Predictors of a protean career orientation and vocational training enrollment in the post-school transition. Journal of Vocational Behavior, 112, 216-228. https://doi.org/10. 1016/j.jvb.2019.03.002

Urbanavičiūtè, I., Bagdžiūnienè, D., Lazauskaite-Zabielskè, J., Vander Elst, T., \& De Witte, H. (2015). The role of career factors in qualitative and quantitative job insecurity: A study in different organizational contexts. International Journal of Psychology: A Biopsychosocial Approach, 16, 23-45. https://doi.org/10.7220/2345-024X. 16.2

Valero, D., \& Hirschi, A. (2019). To hangover or not: Trajectories of job satisfaction in adolescent workforce newcomers. European Journal of Work and Organizational Psychology, 28, 150-163. https://doi.org/10.1080/13 59432X.2018.1564278

Vuolo, M., Mortimer, J. T., \& Staff, J. (2014). Adolescent precursors of pathways from school to work. Journal of Research on Adolescence, 24, 145-162. https://doi.org/10.1111/jora.12038

Yakushko, O., Backhaus, A., Watson, M., Ngaruiya, K., \& Gonzalez, J. (2008). Career development concerns of recent immigrants and refugees. Journal of Career Development, 34, 362-396. https://doi.org/10.1177/ 0894845308316292

\section{Author Biographies}

Jonas Masdonati is a professor of career counseling at the Institute of psychology of the University of Lausanne, Switzerland, where he is member of the Research center in vocational psychology and career counseling (CePCO), the Education and training observatory (OBSEF) and the Swiss center of expertise in life course research (LIVEs). He is president of the European Society for Vocational Designing and Career Counseling (ESVDC). His research interests and activities mainly focus on career transitions, the meaning of work, decent work, occupational identities, and vocational education and training. In his free time, he enjoys photography, reading, and mountain hiking.

Koorosh Massoudi is a senior lecturer at the University of Lausanne, a member of the Research center in vocational psychology and career counseling (CePCO) and an advanced researcher in the Swiss center of expertise in life course research LIVEs. His activities aim at the promotion of health and well-being in the workplace and the professional integration of vulnerable groups. When he s not working or reflecting on the perfectible state of the world, his dedication goes to his wife and daughter, the two loves of his life.

David L. Blustein is a professor and Duganne Faculty Fellow in the Department of Counseling, Developmental, and Educational Psychology at the Lynch School of Education and Human Development at Boston College. He is a fellow of Division 17 (counseling psychology) of the American Psychological Association, and he has received the NCDA Eminent Career Award and the Elizabeth Hurlock Beckman Award. He has published in the areas of career development, the interface between work and relational functioning, and psychology of working theory. He has published a book entitled The Psychology of Working: A New Perspective for Career Development, Counseling, and Public Policy and the recently published The Importance of Work in an Age of Uncertainty: The Eroding 
Work Experience in America. His main interests outside of work are his family, music, politics, art, exercise, and film.

Ryan D. Duffy is a professor of psychology at the University of Florida and training director of the Counseling Psychology program. He received his BA in human development and philosophy from Boston College and his $\mathrm{MA}$ and $\mathrm{PhD}$ from the University of Maryland in counseling psychology. His main areas of research interest are in the psychology of working and work as a calling. He dreams about having interesting and exciting leisure interests but mainly spends his free time watching television and having excessively long conversations about interpersonal relationships and what makes life happy. 